\section{Journal of Computer Networks, Architecture and High Performance Computing}

Volume 3, Number 2, July 2021

https://doi.org/10.47709/cnahpc.v3i2.1071
Submitted : 08-28-2021

Accepted : 09-19-2021

Published : 09-21-2021

\title{
College Ranking Analysis Using VIKOR Method
}

\author{
Adidtya Perdana ${ }^{1 *}$, Arief Budiman ${ }^{2)}$ \\ ${ }^{12)}$ Universitas Harapan Medan, Indonesia \\ 1)
}

\begin{abstract}
College ranking is the main thing used as a basis to attract prospective new students. Prospective new students will generally look for related information from which universities are the best to choose in the future. In the ranking of universities based on the official page of the Ministry of Research, Technology and Higher Education, the ranking of universities, both public and private, can be a reference for recruiting prospective students. The better the college ranking, the more attractive prospective new students are. To determine the ranking of a university, a decision support system is needed. There are many methods available from the decision support system, but in this study, the author will use the VIKOR method (Visekriterijumsko Kompromisno Rangiranje), which is part of the MCDM (Multi-Criteria Decision Making), as a solution to these problems. The VIKOR method is a multi-criteria optimization method that can be used on fairly complex systems. In this study, the sample data used came from 10 universities in the city of Medan, where the initials of each naming were colleges A to J. From the results of research analysis using the VIKOR method, the ranking results were as follows, where college B got the first rank with the lowest score of 0 . Then the second rank was college $\mathrm{G}$ and in the third rank was college $\mathrm{H}$ with each score of 0.248211396 and 0.304702661 . For the fourth, fifth, sixth, seventh to tenth ranks, they are sorted from colleges A, I, C, E, F, D, and J.
\end{abstract}

Keywords: VIKOR Method; College Ranking; Decision Support System; Universities; MCDM

\section{INTRODUCTION}

In this article, we will discuss the ranking of universities, where research on the ranking of campuses is a follow-up study from previous research that the author did with the team. Where previous studies discussed the same case, namely ranking universities using the MAUT (Multi-Attribute Utility Theory) method (Perdana \& Budiman, 2020) and research using the TOPSIS method (Lestari \& Mardiana, 2020). In the ranking of universities based on what is explained on the official page of the Ministry of Research, Technology and Higher Education, the ranking of universities, both public and private, can be a reference for recruiting prospective students. The better the ranking of a college, the more attractive prospective new students are. To determine the ranking of a university, a mapping scheme is needed under the auspices of the Ministry of Research, Technology, and Higher Education (now Kemdikbudristek) as a condition for improving the quality of higher education on a regular and sustainable basis. Quoted from the official website, 5 assessment components form the basis for ranking universities including Quality of Human Resources, Quality of Institutions, Quality of Student Activities, Quality of Publications, Research and Community Service, and Quality of Innovation (Kemenristekdikti, 2018; Perdana \& Budiman, 2020).

To prove the ranking of quality universities, it is necessary to apply a good method. Previously, the application of the MAUT and TOPSIS methods was able to provide almost similar ranking results, namely the university which was denoted by the name B became the first rank of the application of these methods. And to expand the ranking results, the VIKOR method will be used as a new method to solve higher education ranking problems (Lestari \& Mardiana, 2020; Perdana \& Budiman, 2020).

The VIKOR (Visekriterijumsko Kompromisno Rangiranje) method itself is one of the Multi-Criteria Decision Making (MCDM) methods where this method can make decisions from multiple criteria. VIKOR can rank alternatives and can find solutions that are close to the ideal compromise solution (Umam, Sulastri, Andini, Sutiksno, \& Mesran, 2018). The use of the VIKOR method itself can solve several problems such as determining the priority of superior products (Umam et al., 2018), selecting outstanding employees (Wijaya \& Mesran, 2019),

* Corresponding author 


\section{Journal of Computer Networks, Architecture and High Performance Computing}

Volume 3, Number 2, July 2021

https://doi.org/10.47709/cnahpc.v3i2.1071
Submitted : 08-28-2021

Accepted : 09-19-2021

Published : 09-21-2021

selecting recommended products such as the best Electone keyboard musical instrument (Arisandi \& Pribadi, 2020), and much more. So that the application of the VIKOR method in ranking universities is expected to be able to provide the desired results following the criteria and weighting.

\section{LITERATURE REVIEW}

Research conducted by (Sianturi, Wulan, Suginam, Rohminatin, \& Mesran, 2018) stated that the application of the VIKOR method in determining the best leather material for making belts was able to provide a material selection that was closer to the ideal solution using linear normalization. In addition, the study (Imandasari \& Windarto, 2018) that applied the VIKOR method in selecting baby diapers based on skin type based on the criteria used and determined and the appropriate weighting of the assessment was very useful in helping make decisions based on warning of compromise alternatives from several existing alternatives.

In research related to university rankings, this is a follow-up study from previous research conducted by the author. The use of the MAUT Method can provide optimal and ideal ranking results according to the application of the method (Perdana \& Budiman, 2020). Compared to research using the TOPSIS method, the ranking results also provide an optimal and ideal solution (Lestari \& Mardiana, 2020). However, the overall results of the two studies gave slightly different results. For the first rank, the two methods give the same results, but the second to tenth ranks give slightly different results. This is because the process, weighting, and stages of the two methods are different.

In addition to selection and ranking, the VIKOR method is also able to solve selection problems. Where the research was conducted by Yogi Primadasa who applied the VIKOR method in selecting bonus receipts for Indihome salesmen where the results obtained were the desired results where the salesmen with the lowest Qi values received bonuses (Primadasa \& Juliansa, 2019).

In theory, the VIKOR method or Vise Kriterijumska Optimizacija I Kompromisno Resenje or Visekriterijumsko Kompromisno Rangiranje is a multi-criteria optimization method that can be used on fairly complex systems. The focus of this method is on ranking and selecting from a set of alternatives and determining compromise solutions in cases of conflicting criteria that can assist decision-makers in reaching a final decision (Handayani \& Marpaung, 2021; Nasution \& Ulfa, 2020). This compromise solution itself is the most feasible solution that is close to the ideal, and compromise means an agreement established with mutual concessions (Kusuma \& Ginting, 2020).

The stages in calculating the VIKOR method are as follows (Torlak, Demir, \& Budur, 2021; Yusnaeni \& Marlina, 2019):

1) Determine the decision matrix of alternatives and criteria with measures $\left(\mathrm{F}_{\mathrm{mxn}}\right)$

2) Determining Criteria Weight (W)

$$
F=\underset{A 1}{A}\left[\begin{array}{ccc}
a_{11} & \cdots & a_{1 n} \\
\vdots & \ddots & \vdots \\
a_{m 1} & \cdots & a_{m n}
\end{array}\right]
$$

$$
\sum_{j=1}^{n} w_{j}=1
$$

3) Create a normalization matrix by determining positive and negative values as the ideal solution for each criterion.

The decision matrix of alternatives and criteria $(\mathrm{F})$ is normalized by the equation:

$$
N_{i j}=\frac{f^{+}-f_{i j}}{f^{+}-f^{-}}
$$

To determine the positive and negative values of all alternatives, you can use the following Max and Min functions:

$$
\begin{aligned}
& f^{+}=\max \left(f_{1 j}, f_{2 j}, f_{3 j}, \ldots, f_{m j}\right) \\
& f^{-}=\min \left(f_{1 j}, f_{2 j}, f_{3 j}, \ldots, f_{m j}\right)
\end{aligned}
$$

4) Determine the weighted value of the normalized data for each alternative and criteria.

\footnotetext{
* Corresponding author
} 


\section{Journal of Computer Networks, Architecture and High Performance Computing}

Volume 3, Number 2, July 2021

https://doi.org/10.47709/cnahpc.v3i2.1071
Submitted : 08-28-2021

Accepted : 09-19-2021

Published : 09-21-2021

This is done by multiplying the normalized data value $(\mathrm{N})$ with the criterion weight value $(\mathrm{W})$ which has been determined by calculation:

$$
F_{i j}^{*}=w_{j} \cdot N_{i j}
$$

5) Calculates the value of Utility Measure (S) and Regret Measure (R).

To calculate the Utility Measure (S) use the following formula:

$$
S_{j}=\sum_{j=1}^{n}\left[w_{i}\left(\frac{f^{+}-f_{i j}}{f^{+}-f^{-}}\right)\right]
$$

And to calculate Regret Measure $(\mathrm{R})$ use the following formula:

6) Do Ranking.

$$
R_{j}=\sum_{j=1}^{n} \max _{j}\left[w_{i}\left(\frac{f^{+}-f_{i j}}{f^{+}-f^{-}}\right)\right]
$$

The results of the sorting are determined from the lowest value with a compromise solution as the ideal solution. This means that the lower the $\mathrm{Q}_{\mathrm{i}}$ ranking value, the higher it can be placed.

\section{1.}

\section{Subject, Object, and Research Data}

\section{METHOD}

The data or subjects used in this study are universities in the city of Medan. However, to avoid problems and maintain the code of ethics, the names of universities will be disguised in alphabetical order. 10 Universities will be inspected with the following data:

1) HR data such as the number of lecturers based on education, functional position, and class,

2) Institutional data includes PT Accreditation, Study Program Accreditation, and Total Cooperation between domestic and foreign universities,

3) Data on Student Activities owned by the university.

4) Data of scientific publications in the form of seminars, national and international journals, Research Data, and Community Service Data,

5) Innovation data owned by the university.

The object or what will be researched is the ranking of universities/colleges based on the criteria used and the calculation process of the VIKOR Method. And the variables used as the assessment criteria are as follows:

1) Quality of Human Resources

2) Institutional Quality

3) Quality of Student Activities

4) Quality of Publication, Research, and Community Service

5) Innovation Quality

\section{Determination of Data and Criteria}

In this section, what criteria will be used and the weighting for each criterion will be determined. 10 criteria will be used in this study. The criteria and weighting are as follows:

1) $\mathrm{C} 1=$ Percentage of Number of Lecturers and Students, weight : $10 \%$

2) $\mathrm{C} 2=$ Lecturer with $\mathrm{S} 1$ education, weight : $10 \%$

3) $\mathrm{C} 3=$ Lecturer with $\mathrm{S} 2$ Education, weight : $10 \%$

4) $\mathrm{C} 4=$ Lecturer with $\mathrm{S} 3$ Education, weight : $10 \%$

5) $\mathrm{C} 5=$ College Accreditation, weight : $20 \%$

6) $\mathrm{C} 6=$ Student Activities, weight : $5 \%$

7) $\mathrm{C} 7=$ Research (Institutional Status), weight : 10\%

8) $\mathrm{C} 8=$ Community Service (Institutional Status), weight : 10\%

9) C9 = Publication (Sinta's Rank), weight : 10\%

* Corresponding author 
Journal of Computer Networks, Architecture and

High Performance Computing

Submitted : 08-28-2021

Volume 3, Number 2, July 2021

https://doi.org/10.47709/cnahpc.v3i2.1071

Accepted : 09-19-2021

Published : 09-21-2021

10) $\mathrm{C} 10=$ Innovation, weight : $5 \%$

After the criteria and weighting have been made, the next step is to display in detail the data that will be used.

Table 1

Data Used

\begin{tabular}{cccccccccccc}
\hline No & Nama & C1 & C2 & C3 & C4 & C5 & C6 & C7 & C8 & C9 & C10 \\
\hline 1 & A & 50.8 & 1 & 201 & 32 & B & 0.074 & Madya & Memuaskan & 288 & 0 \\
2 & B & 42 & 18 & 450 & 70 & A & 0.708 & Utama & Sangat Bagus & 231 & 0 \\
3 & C & 15 & 8 & 293 & 41 & B & 0 & Madya & Memuaskan & 110 & 0 \\
4 & D & 17.7 & 14 & 166 & 7 & C & 0.226 & Madya & Memuaskan & 346 & 0 \\
5 & E & 33.4 & 9 & 148 & 13 & B & 0.163 & Binaan & Memuaskan & 411 & 0 \\
6 & F & 64.6 & 4 & 86 & 14 & C & 0.034 & Madya & Memuaskan & 362 & 0 \\
7 & G & 45 & 10 & 289 & 32 & B & 0.129 & Madya & Memuaskan & 214 & 0 \\
8 & H & 37.7 & 46 & 265 & 50 & B & 0 & Binaan & Kurang Memuaskan & 195 & 0 \\
9 & 1 & 34 & 2 & 223 & 25 & B & 0.094 & Madya & Memuaskan & 242 & 0 \\
10 & J & 1.1 & 3 & 57 & 1 & - & 0 & Binaan & Kurang Memuaskan & 1302 & 0 \\
\hline
\end{tabular}

Because the criteria for the alternative still have a value that is not a number so that it will be difficult to calculate using the VIKOR method, it will be changed as follows:

Table 2

Customized Data

\begin{tabular}{cccccccccccc}
\hline No & Nama & C1 & C2 & C3 & C4 & C5 & C6 & C7 & C8 & C9 & C10 \\
\hline 1 & A & 50.8 & 1 & 201 & 32 & 3 & 0.074 & 3 & 3 & 288 & 0 \\
2 & B & 42 & 18 & 450 & 70 & 4 & 0.708 & 4 & 4 & 231 & 0 \\
3 & C & 15 & 8 & 293 & 41 & 3 & 0 & 3 & 3 & 110 & 0 \\
4 & $\mathrm{D}$ & 17.7 & 14 & 166 & 7 & 2 & 0.226 & 3 & 3 & 346 & 0 \\
5 & $\mathrm{E}$ & 33.4 & 9 & 148 & 13 & 3 & 0.163 & 2 & 3 & 411 & 0 \\
6 & $\mathrm{~F}$ & 64.6 & 4 & 86 & 14 & 2 & 0.034 & 3 & 3 & 362 & 0 \\
7 & $\mathrm{G}$ & 45 & 10 & 289 & 32 & 3 & 0.129 & 3 & 3 & 214 & 0 \\
8 & $\mathrm{H}$ & 37.7 & 46 & 265 & 50 & 3 & 0 & 2 & 2 & 195 & 0 \\
9 & 1 & 34 & 2 & 223 & 25 & 3 & 0.094 & 3 & 3 & 242 & 0 \\
10 & $\mathrm{~J}$ & 1.1 & 3 & 57 & 1 & 1 & 0 & 2 & 2 & 1302 & 0 \\
\hline
\end{tabular}

2.

RESULT

In this section, we will explain how the VIKOR Method is applied to university/college rankings.

Step 1: Develop a matrix (F) of the final decision to be processed according to the data above.

* Corresponding author

$F=\left|\begin{array}{|cccccccccc|}50.8 & 1 & 201 & 32 & 3 & 0.074 & 3 & 3 & 288 & 0 \\ 42 & 18 & 450 & 70 & 4 & 0.708 & 4 & 4 & 231 & 0 \\ 15 & 8 & 293 & 41 & 3 & 0 & 3 & 3 & 110 & 0 \\ 17.7 & 14 & 166 & 7 & 2 & 0.226 & 3 & 3 & 346 & 0 \\ 33.4 & 9 & 148 & 13 & 3 & 0.163 & 2 & 3 & 411 & 0 \\ 64.6 & 4 & 86 & 14 & 2 & 0.034 & 3 & 3 & 362 & 0 \\ 45 & 10 & 289 & 32 & 3 & 0.129 & 3 & 3 & 214 & 0 \\ 37.7 & 46 & 265 & 50 & 3 & 0 & 2 & 2 & 195 & 0 \\ 34 & 2 & 223 & 25 & 3 & 0.094 & 3 & 3 & 242 & 0 \\ 1.1 & 3 & 57 & 1 & 1 & 0 & 2 & 2 & 1302 & 0\end{array}\right|$


Journal of Computer Networks, Architecture and

High Performance Computing

Submitted : 08-28-2021

Volume 3, Number 2, July 2021

https://doi.org/10.47709/cnahpc.v3i2.1071

Accepted : 09-19-2021

Published : 09-21-2021

Step 2: Determine the weight of the criteria from the data that has been described previously so that the criteria weight $(\mathrm{W})$ is obtained as follows:

$$
W=\left|\begin{array}{llllllllll}
0.1 & 0.1 & 0.1 & 0.1 & 0.2 & 0.05 & 0.1 & 0.1 & 0.1 & 0.05
\end{array}\right|
$$

Step 3: Create a normalized matrix $(\mathrm{N})$. Previously, the positive value $\left(\mathrm{f}^{\dagger}\right)$ and negative value (f) of each criterion had to be calculated.

Table 3

Positive Value and Negative Value from Criteria

\begin{tabular}{|c|c|c|c|c|c|c|c|c|c|c|}
\hline & $\mathrm{C} 1$ & $\mathrm{C} 2$ & C3 & $\mathrm{C} 4$ & $\mathrm{C} 5$ & C6 & C7 & C8 & C9 & $\mathrm{C} 10$ \\
\hline $\mathrm{f}^{+}$ & 64.6 & 46 & 450 & 70 & 4 & 0.708 & 4 & 4 & 1302 & 0 \\
\hline $\mathrm{f}$ & 1.1 & 1 & 57 & 1 & 1 & 0 & 2 & 2 & 110 & 0 \\
\hline
\end{tabular}

After the positive and negative values are obtained, the next step is to calculate the normalization of the matrix $(\mathrm{N})$. The results of the matrix normalization calculation will be presented as follows:

$N=\left|\begin{array}{cccccccccc|}0.217323 & 1 & 0.633588 & 0.550725 & 0.333333 & 0.89548 & 0.5 & 0.5 & 0.850671 & 0 \\ 0.355906 & 0.622222 & 0 & 0 & 0 & 0 & 0 & 0 & 0.89849 & 0 \\ 0.781102 & 0.844444 & 0.399491 & 0.42029 & 0.333333 & 1 & 0.5 & 0.5 & 1 & 0 \\ 0.738583 & 0.711111 & 0.722646 & 0.913043 & 0.666667 & 0.680791 & 0.5 & 0.5 & 0.802013 & 0 \\ 0.491339 & 0.822222 & 0.768448 & 0.826087 & 0.333333 & 0.769774 & 1 & 0.5 & 0.747483 & 0 \\ 0 & 0.933333 & 0.926209 & 0.811594 & 0.666667 & 0.951977 & 0.5 & 0.5 & 0.788591 & 0 \\ 0.308661 & 0.8 & 0.409669 & 0.550725 & 0.333333 & 0.817797 & 0.5 & 0.5 & 0.912752 & 0 \\ 0.423622 & 0 & 0.470738 & 0.289855 & 0.333333 & 1 & 1 & 1 & 0.928691 & 0 \\ 0.48189 & 0.977778 & 0.577608 & 0.652174 & 0.333333 & 0.867232 & 0.5 & 0.5 & 0.889262 & 0 \\ 1 & 0.955556 & 1 & 1 & 1 & 1 & 1 & 1 & 0 & 0\end{array}\right|$

Step 4: Multiplying the Normalized Decision Matrix (N) with the criteria weight (W) to produce a Weighted Normalization Matrix $\left(\mathrm{F}^{*}\right)$ as follows:

\begin{tabular}{|c|c|c|c|c|c|c|c|c|c|c|}
\hline & 0.021732283 & 0.1 & 0.063358779 & 0.055072464 & 0.066666667 & 0.044774011 & 0.05 & 0.05 & 0.085067114 & 0 \\
\hline & 0.035590551 & 0.062222222 & 0 & 0 & 0 & 0 & 0 & 0 & 0.089848993 & 0 \\
\hline & 0.078110236 & 0.084444444 & 0.039949109 & 0.042028986 & 0.066666667 & 0.05 & 0.05 & 0.05 & 0.1 & 0 \\
\hline & 0.073858268 & 0.071111111 & 0.072264631 & 0.091304348 & 0.133333333 & 0.034039548 & 0.05 & 0.05 & 0.080201342 & 0 \\
\hline & 0.049133858 & 0.082222222 & 0.076844784 & 0.082608696 & 0.066666667 & 0.038488701 & 0.1 & 0.05 & 0.074748322 & 0 \\
\hline & 0 & 0.093333333 & 0.092620865 & 0.08115942 & 0.133333333 & 0.04759887 & 0.05 & 0.05 & 0.07885906 & 0 \\
\hline & 0.030866142 & 0.08 & 0.040966921 & 0.055072464 & 0.066666667 & 0.040889831 & 0.05 & 0.05 & 0.091275168 & 0 \\
\hline & 0.042362205 & 0 & 0.047073791 & 0.028985507 & 0.066666667 & 0.05 & 0.1 & 0.1 & 0.092869128 & 0 \\
\hline & 0.048188976 & 0.097777778 & 0.057760814 & 0.065217391 & 0.0666666667 & 0.043361582 & 0.05 & 0.05 & 0.088926174 & 0 \\
\hline & 0.1 & 0.095555556 & 0.1 & 0.1 & 0.2 & 0.05 & 0.1 & 0.1 & 0 & 0 \\
\hline
\end{tabular}

Step 5: Calculates Utility Measures (S) and Regret Measures (R) as follows:

Table 4

Utility Measure (S) and Regret Measure (R) Values

\begin{tabular}{lccc}
\hline S1 & 0.536671318 & R1 & 0.1 \\
S2 & 0.187661767 & R2 & 0.089849 \\
S3 & 0.561199442 & R3 & 0.1 \\
S4 & 0.656112581 & R4 & 0.133333 \\
S5 & 0.620713249 & R5 & 0.1 \\
S6 & 0.626904883 & R6 & 0.133333 \\
S7 & 0.505737192 & R7 & 0.091275 \\
\hline
\end{tabular}

* Corresponding author

This is an Creative Commons License This work is licensed under a

Creative Commons Attribution-NoDerivatives 4.0 International License. 
Journal of Computer Networks, Architecture and

High Performance Computing

Submitted : 08-28-2021

Volume 3, Number 2, July 2021

https://doi.org/10.47709/cnahpc.v3i2.1071

Accepted : 09-19-2021

Published : 09-21-2021

\begin{tabular}{cccc}
\hline S8 & 0.527957298 & R8 & 0.1 \\
S9 & 0.567899383 & R9 & 0.097778 \\
S10 & 0.845555556 & R10 & 0.2 \\
\hline
\end{tabular}

Step 6: Calculating the VIKOR index value $(Q)$.

Before calculating the VIKOR index value (Q) from each alternative, first calculate the values such as $\mathrm{S}^{+}, \mathrm{S}^{-}, \mathrm{R}^{+}$, and $\mathrm{R}^{-}$as follows:

$$
\begin{aligned}
& S^{+}=\max \left\{S_{1}, S_{2}, S_{3}, S_{4}, \ldots, S_{10}\right\}=0.845555556 \\
& S^{-}=\min \left\{S_{1}, S_{2}, S_{3}, S_{4}, \ldots, S_{10}\right\}=0.187661767 \\
& R^{+}=\max \left\{R_{1}, R_{2}, R_{3}, R_{4}, \ldots, R_{10}\right\}=0.2 \\
& R^{-}=\min \left\{R_{1}, R_{2}, R_{3}, R_{4}, \ldots, R_{10}\right\}=0.089848993
\end{aligned}
$$

For the calculation of the VIKOR index of each alternative where there is a variable $v$ with a value of 0.5 so that it produces the following values:

Table 5

VIKOR Index Calculation Results

\begin{tabular}{ccc}
\hline $\begin{array}{c}\text { Alternative } \\
\text { Code }\end{array}$ & Colleges Name & Q \\
\hline A1 & A & 0.311325326 \\
A2 & B & 0 \\
A3 & C & 0.329966727 \\
A4 & D & 0.553408255 \\
A5 & E & 0.375197286 \\
A6 & F & 0.531210372 \\
A7 & G & 0.248211396 \\
A8 & H & 0.304702661 \\
A9 & 1 & 0.324971527 \\
A10 & J & 1 \\
\hline
\end{tabular}

Step 7: perform a ranking of alternatives based on the value of $Q$ in ascending order (from smallest to largest).

Table 6

College Ranking Results using the VIKOR Method

\begin{tabular}{ccc}
\hline $\begin{array}{c}\text { Colleges } \\
\text { Name }\end{array}$ & Ranking & Score \\
\hline B & 1 & 0 \\
G & 2 & 0.248211396 \\
H & 3 & 0.304702661 \\
A & 4 & 0.311325326 \\
I & 5 & 0.324971527 \\
C & 6 & 0.329966727 \\
E & 7 & 0.375197286 \\
F & 8 & 0.531210372 \\
D & 9 & 0.553408255 \\
J & 10 & 1 \\
\hline
\end{tabular}

\section{DISCUSSIONS}

From the results given by the calculation of the VIKOR Method on the ranking of universities, the results are as shown in Table 6. Where college B gets the first rank with the lowest score of 0 . Furthermore, the second-ranked is * Corresponding author 
Journal of Computer Networks, Architecture and

High Performance Computing

Volume 3, Number 2, July 2021

https://doi.org/10.47709/cnahpc.v3i2.1071
Submitted : 08-28-2021

Accepted : 09-19-2021

Published : 09-21-2021

college $\mathrm{G}$ and the third rank is college $\mathrm{H}$ with each score is 0.248211396 and 0.304702661 . The fourth, fifth, sixth, seventh to tenth rankings are sorted from universities A, I, C, E, F, D, and J. When compared with the MAUT and TOPSIS methods, the differences are as follows (comparative data taken from sources (Perdana \& Budiman, 2020) and (Lestari \& Mardiana, 2020)):

Table 7

\begin{tabular}{cccc}
\multicolumn{4}{c}{ Comparison of Results from VIKOR, MAUT, and TOPSIS Methods } \\
\hline \multirow{4}{*}{ VIKOR } & MAUT & TOPSIS \\
\cline { 2 - 4 } & B & B & B \\
G & I & C \\
Ranking Perguruan & C & A & I \\
Tinggi & A & G & A \\
& I & D & G \\
& C & F & F \\
& E & E & E \\
F & H & H \\
D & J & J \\
J & & &
\end{tabular}

From table 7 it can be seen that among the three methods, namely VIKOR, MAUT, and TOPSIS, the results are quite different, but the first rank gives the same result, namely college B and the tenth rank gives the same result, namely college J. ninth gave varying results. It can be concluded that the use of decision support system methods such as VIKOR, MAUT, TOPSIS, and others can provide optimal results even though the overall results may vary. In the case of university rankings, it can provide the same results for the first and last ranks, but for other rankings, it can be different.

\section{CONCLUSION}

The VIKOR method can be used in making a decision, one of which is the ranking of universities. In the calculation, the ranking result that will be displayed is the lowest value. From the results of the analysis of 10 samples of higher education data used, the final results for the ranking of universities are obtained, where college B gets the first rank with the lowest score of 0 . Then, the second-ranked is college $\mathrm{G}$ and in the third rank is college $\mathrm{H}$ with each -score 0.248211396 and 0.304702661 respectively. For the fourth, fifth, sixth, seventh to tenth ranks, they are sorted from colleges A, I, C, E, F, D, and J.

\section{REFERENCES}

Arisandi, A., \& Pribadi, E. S. (2020). Analisa Metode VIKOR pada Rekomendasi Alat Musik Keyboard Electone Terbaik. KESATRIA: Jurnal Penerapan Sistem Informasi (Komputer \& Manajemen), 1(1), $31-36$.

Handayani, M., \& Marpaung, N. (2021). IMPLEMENTASI METODE VIKOR SEBAGAI PENDUKUNG KEPUTUSAN KARYAWAN PENERIMA REWARD. Journal of Science and Social Research, IV(2), 171-179.

Imandasari, T., \& Windarto, A. P. (2018). Penerapan Metode VIKOR Pada Pemilihan Popok Bayi Berdasarkan Jenis Kulit. Seminar Nasional Sains \& Teknologi Informasi (SENSASI), 215-220.

Kemenristekdikti. (2018). Kemenristekdikti Umumkan Peringkat 100 Besar Perguruan Tinggi Indonesia Non Vokasi Tahun 2018. Retrieved February 12, 2019, from Kemenristekdikti website: https://ristekdikti.go.id/kabar/kemenristekdikti -umumkan-peringkat-100-besar-perguruan- tinggiindonesia-non-vokasi-tahun-2018/

Kusuma, A., \& Ginting, G. (2020). Sistem Pendukung Keputusan Pemilihan Apoteker Terbaik Pada PT

\footnotetext{
* Corresponding author
} 
Kimia Farma ( Persero ) Tbk Medan Menerapkan Metode Vikor. Jurnal Sistem Komputer Dan Informatika (JSON), 1(3), 252-257. https://doi.org/10.30865/json.v1i3.2163

Lestari, Y. D., \& Mardiana, M. (2020). Decision Support System For Determining the Best College High Private Using Topsis Method. SinkrOn : Jurnal Dan Penelitian Teknik Informatika, 4(2), 27-33.

Nasution, A., \& Ulfa, K. (2020). Sistem Pendukung Keputusan Kelayakan Pemberian Asuransi Jiwa Untuk Nelayan dengan Menggunakan Metode Vikor ( Studi Kasus : Dinas Kelautan dan Perikanan Medan ). Jurnal Sistem Komputer Dan Informatika (JSON), 1(3), 220-225. https://doi.org/10.30865/json.v1i3.2162

Perdana, A., \& Budiman, A. (2020). Analysis of Multi-attribute Utility Theory for College Ranking Decision Making. SinkrOn : Jurnal Dan Penelitian Teknik Informatika, 4(2), 19-26.

Primadasa, Y., \& Juliansa, H. (2019). Penerapan Metode Vikor dalam Seleksi Penerimaan Bonus Pada Salesman Indihome. Jurnal Teknologi Informasi \& Komunikasi Digital Zone, 10(1), 33-43.

Sianturi, M., Wulan, S., Suginam, S., Rohminatin, R., \& Mesran, M. (2018). Implementasi Metode VIKOR Untuk Menentukan Bahan Kulit Terbaik Dalam Pembuatan Ikat Pinggang. Jurnal Riset Komputer (JURIKOM), 5(1), 56-60.

Torlak, N. G., Demir, A., \& Budur, T. (2021). Using VIKOR with structural equation modeling for constructing benchmarks in the Internet industry. Benchmarking: An International Journal, (2002). https://doi.org/10.1108/BIJ-09-2020-0465

Umam, K., Sulastri, V. E., Andini, T., Sutiksno, D. U., \& Mesran, M. (2018). Perancangan Sistem Pendukung Keputusan Penentuan Prioritas Produk Unggulan Daerah Menggunakan Metode VIKOR. Jurnal Riset Komputer (JURIKOM), 5(1), 43-49.

Wijaya, I., \& Mesran, M. (2019). Penerapan Metode AHP dan VIKOR Dalam Pemilihan Karyawan Berprestasi. Seminar Nasional Teknologi Komputer \& Sains (SAINTEKS), 301-309.

Yusnaeni, W., \& Marlina, M. (2019). PEMERINGKATAN PENILAIAN KINERJA KARYAWAN MELALUI METODE AHP DAN VIKOR. Jurnal Pilar Nusa Mandiri, 15(2), 203-210. https://doi.org/10.33480/pilar.v15i2.715 